\title{
Global Illicit Financial Flows: Where does Dirty Money from Developing Countries become legal?
}

\author{
Wahaj Ahmed Khan * $\quad$ Syed Tehseen Jawaid ${ }^{\dagger} \quad$ Muhammad Asif Shamim ${ }^{\ddagger}$
}

\begin{abstract}
The study determines most favorite destinations for money laundering preferred by wrong doers from 25 developing nations selected on the basis of highest illegal financial fund outflows from 2004 to 2014, a report published by Global Financial Integrity (GFI) in 2015. Firstly, it has been discussed that how money laundering activities are shackling the economic and financial stability in a country by distorting and damaging different sectors of economy as well as financial sector. Walker's Gravity Model has used to determine the most preferred destinations for money laundering. Research indicates that most developed and stable economies with lax controls are preferred by criminals. Robustness has been checked through triangulation method. It is recommended that uniform controls at global level are essential to eliminate havens and the need of international body which shall be responsible for policy making and enforcement of strong regulations is also highlighted.
\end{abstract}

Keywords: Money laundering, Illicit Financial Flows, Developing Countries.

\section{Introduction}

\section{Money Laundering: A toxin fuel to crime which only attracts harm}

Distancing the illegal proceeds from the source which results in the acquisition of such wealth is as difficult and risky for criminals, corrupt officials, politicians and other wrong doers as those criminal activities themselves. Wealth which is acquired illegally cannot be consumed freely and the utilization of such proceeds raises red flags and attracts law enforcement agencies, the greatest fear of wrong doers. Therefore criminals and other illegal wealth holders are continuously active in hiding their illegal proceeds and moreover transforming the same into the wealth which looks legal. Schneider and Windischbauer (2008) also suggest the same as they propose that all illegal activities require money laundering operations as the revenue generated from those illicit acts are in form of cash. The process which transforms the illegal money into the proceeds which portrait them legal is better

\footnotetext{
*PhD Scholar, Karachi University Business School, University of Karachi, Pakistan.

Email: wahaj1186@gmail.com

$\dagger$ Assistant Professor / Research Economist, Applied Economics Research Centre, University of Karachi, Pakistan. Email: stjawaid@hotmail.com

$\ddagger$ Professor, Faculty of Management Sciences, Department of Accounting and Finance, Salim Habib University, Karachi, Pakistan. Email: asif.shamim@shu.edu.pk
} 
known as money laundering, a three stage process which includes placement, layering and integration.

Crime and Misconduct Commission (2005) suggests that money laundering is an integral part of criminal activities like drug trafficking, white collar crimes, bribery and corruption and this is the reason a huge amount of illegal funds laundered by criminals through different channels. According to United Nations office on Drug and Crime (UNODC) amount which is laundered in a year is $2 \%$ to $5 \%$ of global GDP, if calculated on higher side it is amounted to be 3.89 trillion in US dollars. One can imagine what the mentioned amount can do when it is around $16 \%$ of total GDP of developing the world ${ }^{1}$. Successful money laundering operations promote crimes, as criminal elements can rip the fruit of their ill doings easily.

Money laundering activities have devastating effect on countries, irrespective that the country is losing the wealth in term of illicit outflow of funds or whether receiving the funds as the bad money attracts bad stuff to economy and society. Money laundering activities result in unexplained changes on balance of payment. It also affects money supply, exchange rate and market volatility (Schneider \& Windischbauer, 2008). Illegal money attracts like minded people in an organization or in a country which results in an increase in crime, corruption and bribery. Once criminals set up their roots firmly they try to increase the political control to achieve more gains from their illegal activities. This attempt of wrongdoers affects the economic and social stability of a country. Same is also suggested by Gjoni, Gjoni, and Kora (2015).

Developing nations face severe consequences from money laundering activities as these activities result in draining out of already scarce resources. Money laundering activities reduce the effectiveness of poverty elimination efforts, discourage savings and also cause a lack of investment in poverty reduction programs by diverting resource allocation. According to Nkurunziza (2012) if continent of Africa does not lose so many resources through the illegal outflow of funds, the acute poverty conditions will not be the same. The study also suggests that political elite and leaders of those nations are less bothered to tackle the problem of illegal flow of funds through money laundering activities. The impression that a country is being associated with money laundering activities also has a negative impact on country's development. It also hinders the chances of integration with developed world as the developed countries are less comfortable to work in association of those countries or their financial institutions due to global regulations on money laundering and financial institutions. Gjoni et al. (2015) conclude in the study that Albania faces problems in integration with the European Union because of lack of implementation of regulation required for Albanian institutions.

Money laundering activities mainly focus on the import of luxurious goods which acutely affect the condition of balance of payment in a country. A developing country which already has a low level of foreign reserves faces difficulties in bearing such artificial shocks. On the other end, these activities do not bring any economic benefit to country's economy, same is also suggested by Bartlett (2002). Money laundering allows criminals to convert their illegal proceeds into legitimate wealth and with the successful process of money laundering, criminal activities become more profitable. Comstock (1994) also con-

\footnotetext{
${ }^{1}$ Calculation based on 2015 GDP data of developing countries obtained from World Bank Databank.
} 
firms the same and also suggests that money launderers use financial sector for their illicit activities which also jeopardize the integrity of financial sector of a country.

Once the financial sector of a country gets an impression that the institutions are involved in such illicit activities or there is a lack of interest in implementing regulations related to anti money laundering regime, the other financial institutions and banks started delinking their correspondent banking relations with such countries. This delink of correspondent banking relationship (CBR) hampered the trade business of those countries. One can understand the consequences of delinking, when a developing country is unable to exports due to lack of banking arrangements at a global scale. In 2015 on request of G20 and Financial Stability Board (FSB) World Bank conduct a fact finding exercise to determine the phenomena of delinking of CBR by major banks ${ }^{2}$. World Bank's report shows that there is a major decline in CBR products and services including international money transfer services, remittances, clearing and settlement. According to the above discussed report financial institutions in Caribbean region face most difficulties.

In short, money laundering activities increase the corruption in the society, expand the size of the underground economy as black money creates a parallel economy. It also affects government budget and resources allocation as government agencies are unable to anticipate correct status of the economy due to irregular income distribution and consumption pattern. Society in general bears harsh cost in term of enhanced crime rates, accidents and awful incidents due to poor and untrustworthy public projects and transport systems, which are only allowed because of bribery. It also increases the chances of financial scams in which general public loses their lifetime savings and investments (Myint, 2000). Therefore, it is necessary to put an effective fight against money laundering to reduce aforesaid consequences of money laundering.

In fight against money laundering it is essential for policy makers to determine the destinations from where illegal money generates as well as where it lands for the purpose of money laundering. It is necessary to develop tailor made policies which may be proven more effective than mimic adoption of policies. This study is first effort to determine the favorite destination for money laundering from selected developing countries. Therefore, to answer the question that which countries may be consider as prefered destination for money launderers Walker's Gravity Model best fits as it initially provides the most attractive destinations preferred by money launderers from a country and then facilitates in calculating the amount laundered.

\section{Review of Related Literature}

Previously, we discussed the need of money laundering activities in organized crimes and their impact on economic and financial sectors of a country. Earlier discussion also suggests the need of reliable estimations to counter money laundering activities. However, despite such needs when the current literature related to area of money laundering was reviewed, it is established that very few efforts have been made to uncover this aspect of the topic.

\footnotetext{
${ }^{2}$ Report on the G20 Survey on De Risking activities in the Remittance Market, published by World Bank Group October 2015.
} 
Some of studies which highlight the nature and scope of money laundering, it's negative impacts and other associated issues include (Kumar, 2012; Fontana, 2010), few of these studies are reviewed in brief detail below.

Shelley (1995) discussed the firm establishment of organized criminal groups and its reasons. The article discussed those factors that resulted in the growth of organized crimes. The study also explains the consequences of an increase in organized crimes. The article concluded transitional crimes are growing in rapid pace and continuously try to penetrate political institutions and also trying to weaken genuine economic growth. The study also suggest that post soviet union problems also give rise to transitional crimes and recommends that nations should play their roles in mitigating those criminal activities and establish regulation or otherwise their political and financial institutions get weaken and destabilized by criminal groups.

Unger et al. (2006) estimated the amount of money laundered in and from Netherland by using Walkers Gravity Model. Study first discussed the amount and effects of money laundering. The study also evaluates the need for quantification of money laundering in order to eliminate the problem. According to study non availability of specific definition at the global level also amplifies the problem. Research estimates that around USD \$ 30 billion are laundered through Netherland. It is concluded that there is a shortage of reliable data available for estimation of money laundering and recommended the establishment and monitoring of relevant database which is split over different sections currently.

Ferwerda (2009) discussed the role of anti money laundering policy framework in reducing crimes. Crime data is taken for 17 developed countries from European Sourcebook of Crime and Criminal Justice Statistics. The study suggest that specific values related to anti money laundering policies are not possible to gather, therefore best possible indicators are developed based on certain assumptions and mutual evaluation reports. The hypothesis based on the economics of crime is tested through Mundlak specification in four anti money laundering policy areas including the legal framework, duties of the private sector, institutional framework and international cooperation. Results show the negative relationship as expected in all cases except in one that is an institutional framework which also remains insignificant along with others. The only significant variable is international cooperation which shows the integration of anti money laundering regime at the global level. The study recommends an increase of international cooperation and providing extra incentives to countries adhering anti money laundering policies globally.

Sharman (2008) examines anti money laundering policies in developing countries and their adoption criteria. Data for research is collected through different surveys, observations of participants and interviews. Study first discussed the adoption criteria of anti money laundering policies and background of anti money laundering. The study discussed four of the mainly widespread techniques used for implementing anti money laundering measures which include learning, coercion, mimicry and competition effects. The study concludes that mimicry and competition effect have a strong cause of anti money laundering policy implementation, however, study also suggests that while employing anti money laundering regime local scenario and cost benefit paradox should be considered.

Fontana (2010) discusses the need of estimating money laundering and also evaluates different methods used for estimating the amount of money laundered. The study explains 
the advantages and disadvantages of different methods. It is concluded that there is a need for the estimation of amount laundered in order to counter the money laundering activities. The study recommends improvement of money laundering data and knowledge of money laundering scenarios of different countries.

Gjoni et al. (2015) investigate the effects of money laundering. The relationship between money laundering and globalization are also examined in this article. Firstly money laundering phenomena have been explained along with its methods, money laundering cycle and effects. The study concluded that globalization has a negative impact of countering money laundering as criminals found relieve due to the presence of different methods available to them because of globalization and technological advancement. It is also concluded in the study that countries with lax anti money laundering policies face difficulties in integration process with developed countries.

Colladon and Remondi (2017) explore the use of network analytical techniques to prevent money laundering activities. Internal transaction database of a factoring company has been used for the purpose of analysis. The duties of a factoring company in relation with prevention of money laundering activities while doing business have been discussed. It is suggested that when the data is big and deep, a system based approach is considered more reasonable. Through findings the study suggests that social network metrics are important in assessing risk profile and through combination of different money laundering activities detection tools and consolidation of data at national level to make the detection process more effective.

Hetemi, Merovci, and Gulhan (2018) examine the impact of money laundering phenomena on economic growth. The study suggest technological advancement give ease to money laundering activities and by strengthening rule of law, regulatory framework and legal environment we can reduce the money laundering activities. For the purpose of analysis data from 20 countries has been collected from year 2005 to 2015. Results show that economic growth has negative and significant relationship with money laundering. It is recommended that countries should formulate and implement polices keeping in view the objective to strengthen the fight against money laundering.

Pol (2018) examines the reliability of methodology currently in use for determining the effectiveness of AML regime. Recent articles and other elements on same topic were assessed for the purpose of examination. It is suggested that current methodology is more concerned about the process and outputs rather on the outcomes. It is concluded that effectiveness methodology of FATF is not an outcome oriented approach but the study also emphasized on that it does not mean that FATF policies are less effective. In the end it is recommended that the methodology shall be revisited for improvement.

Demetis (2018) examines the role of technology in detecting money laundering. The study emphasized on the use of human and technology for better detection of money laundering activities in banks. For the purpose of analysis a combination of data gathering is used. The study suggests that human profiling along with computer profiling is critical for detecting money laundering and by reducing complexity of system a bank may get better results in true pointing out of money laundering activities.

Khan, Jawaid, and Arif (2018) examined the illegal flow of funds from Pakistan to China due to extended association of China and Pakistan due to China Pakistan Economic 
Corridor (CPEC). The study suggested that recent studies on CPEC mainly cover the benefits of the project and completely ignoring detriments. The study concluded that illegal flow of funds from Pakistan to China has increased after the inception of CPEC and through Fan Chart analysis it is also predicted that same will be increased in future. The study recommends that concerned authorities should pay great attention to control the illegal out flow of funds or Pakistan will lose a big chunk of its resources under the umbrella of CPEC.

Review of related literature shows that there is a large number of studies done in the field of money laundering. However, mainly those studies focused on defining the process of money laundering, its negative effects and consequences and the efforts made at different levels to counter money laundering. Very few attempts have been made yet to quantify the amount of money laundering despite that almost all researcher accept the importance of quantification of money laundering to counter the problem. Notwithstanding that quantitative analysis is essential to counter money laundering, not many efforts are made in this area. This study attempts to determine preferred destinations for money laundering from developing countries and also tries to highlight some key features which make these destinations most favorite global money launderettes.

\section{Methodology and Data}

As discussed previously to tackle problem of money laundering effectively, a quantitative approach is required to determine favorite destinations. For this purpose modified Walker's Gravity Model has been used for determination of destinations most preferred by top fifteen developing countries with highest illicit financial flows on a global scale.

\section{Sample Size}

The sample size for this study as mentioned in table 1, the list of top 15 developing countries on basis of illicit financial flow.

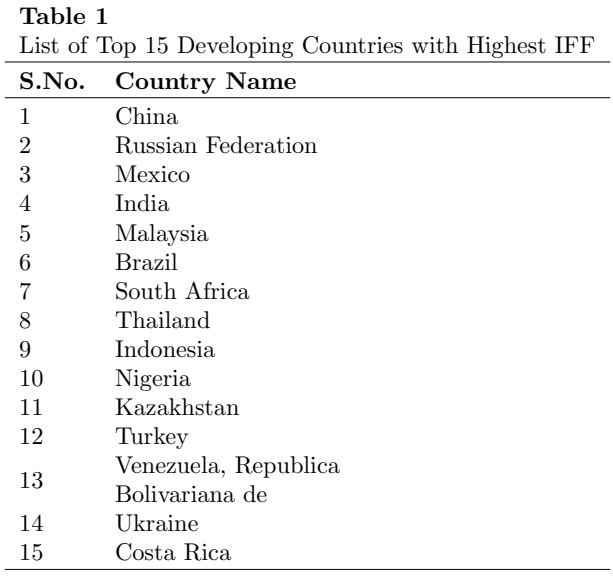


Top fifteen developing countries from where illegal funds are poured out are selected from a report on Illicit Financial Flow from Developing Countries: 2004 to 2013 published by Global Financial Integrity (GFI), a nonprofit advisory organization in 2015. These fifteen base countries contributed $70.51 \%$ of illegal financial flow from developing countries. Furthermore, these countries hold $51.90 \%$ of world's total population and $28.26 \%$ of world's total GDP. For estimation purpose, data is collected from maximum up to 156 destination countries list of which is provided in table 2 .

Table 2

List of Total 156 Countries used for estimations

\begin{tabular}{|c|c|c|c|}
\hline Afghanistan & Cote d'Ivoire & Kazakhstan & Qatar \\
\hline Albania & Croatia & Kenya & Romania \\
\hline Algeria & Cyprus & Korea, South & Russia \\
\hline Angola & Czech Republic & Kuwait & Samoa \\
\hline Argentina & Denmark & Kyrgyzstan & Saudi Arabia \\
\hline Armenia & Djibouti & Laos & Senegal \\
\hline Aruba & Dominica & Latvia & Serbia \\
\hline Australia & Dominican Republic & Lebanon & Seychelles \\
\hline Austria & East Timor & Lesotho & Sierra Leone \\
\hline Azerbaijan & Ecuador & Liberia & Singapore \\
\hline Bahamas, The & Egypt & Libya & Slovakia \\
\hline Bahrain & El Salvador & Lithuania & Slovenia \\
\hline Bangladesh & Fiji & Luxembourg & Solomon Islands \\
\hline Belarus & Finland & Macau & South Africa \\
\hline Belgium & France & Macedonia & Spain \\
\hline Belize & Gambia, The & Madagascar & Sri Lanka \\
\hline Benin & Georgia & Malawi & Sudan \\
\hline Bhutan & Germany & Malaysia & Suriname \\
\hline Bolivia & Ghana & Maldives & Swaziland \\
\hline Bosnia \& Herzegovina & Greece & Mali & Sweden \\
\hline Botswana & Grenada & Malta & Switzerland \\
\hline Brazil & Guinea & Mauritania & Tajikistan \\
\hline Brunei & Guinea-Bissau & Mauritius & Tanzania \\
\hline Bulgaria & Guyana & Mexico & Thailand \\
\hline Burkina Faso & Haiti & Moldova & Togo \\
\hline Burundi & Honduras & Mongolia & Trinidad \& Tobago \\
\hline Cambodia & Hong Kong & Nepal & Tunisia \\
\hline Cameroon & Hungary & Netherlands & Turkey \\
\hline Canada & Iceland & Nicaragua & Uganda \\
\hline Cape Verde & India & Niger & Ukraine \\
\hline Central African Rep. & Indonesia & Nigeria & United Arab Emirates \\
\hline Chad & Iran & Oman & United Kingdom \\
\hline Chile & Iraq & Panama & United States \\
\hline China & Ireland & Papua New Guinea & Uruguay \\
\hline Colombia & Israel & Paraguay & Vanuatu \\
\hline Comoros & Italy & Peru & Venezuela \\
\hline Congo, Dem. Rep. & Jamaica & Philippines & Vietnam \\
\hline Congo, Repub. of the & Japan & Poland & Yemen \\
\hline Costa Rica & Jordan & Portugal & Zambia \\
\hline
\end{tabular}

\section{Walker's Gravity Formula}

Walker's formula to calculate money laundering is based on Newton's Gravity model proposed by Isaac Newton in 1687 and later transmuted by Nobel Prize winner Jan Tinbergen to be used for bilateral trade. Walker's Gravity Model examines the flow of proceeds from one country to another. 
Walker's model does not rely on official data and statistics merely; therefore estimates are not only based on those figures which are officially stated. The model also records transactions only once it enters in the money laundering process and the chances of duplication of recording are removed. Walker's formula has better country coverage and covers more factors which put effects on money laundering activities. This research makes an effort to update another variable in Walker's Gravity Model i.e. Diplomatic Relationship mentioned in formula with DR. This variable is used to nullify all other variables in case there is no existing diplomatic relationship among two countries, because if two different nations do not recognize each other or their diplomatic relations are cut short due to any reason it suggests no other affiliation exists including economic or financial. This implies that funds cannot be moved between these countries. Therefore, mentioned variable may be considered as an important improvement in formula. Same has been suggested by Khan et al. (2018).

$$
P\left(X, y_{i}\right)=\left(\frac{1}{\sum_{i=1}^{n}\left[\operatorname{attractiveness}\left(y_{i}\right) / \operatorname{dist}\left(X, y_{i}\right)\right]^{x}} * \frac{\operatorname{attractiveness}\left(y_{i}\right)}{\operatorname{dist}\left(X, y_{i}\right)}\right) * D R
$$

Above mentioned Walker's Gravity Model further breaks into following segments, which are elucidated below along with the explanation of their variables.

\section{Attractiveness}

$$
\text { Attractiveness }=G D P *(3 * B S+G A+S W I F T+F D-3 * C F-C R-E G+10)
$$

\section{Distance}

$$
\text { Distance }=\text { language }+ \text { trade }+ \text { colonical background }+ \text { physical distance }
$$

\section{Justification on Selection of Variables}

Unger et al. (2006) put light on the selection of variables, same has been explained below for further clarification about the choice of variables opted.

1. GDP per Capita: It reflects attributes of economies as the dirty money is easy to hide in larger and rich economies, therefore, such destinations are preferred by money launderers.

2. Banking Secrecy: If a country has strong banking secrecy laws, it helps out money launderers as the anti money laundering and other law enforcement agencies found it difficult to get timely and desired information in effective manner to counter money laundering.

3. Government Attitude: Countries with tolerant attitude towards money laundering attracts more amount of illegal money. 


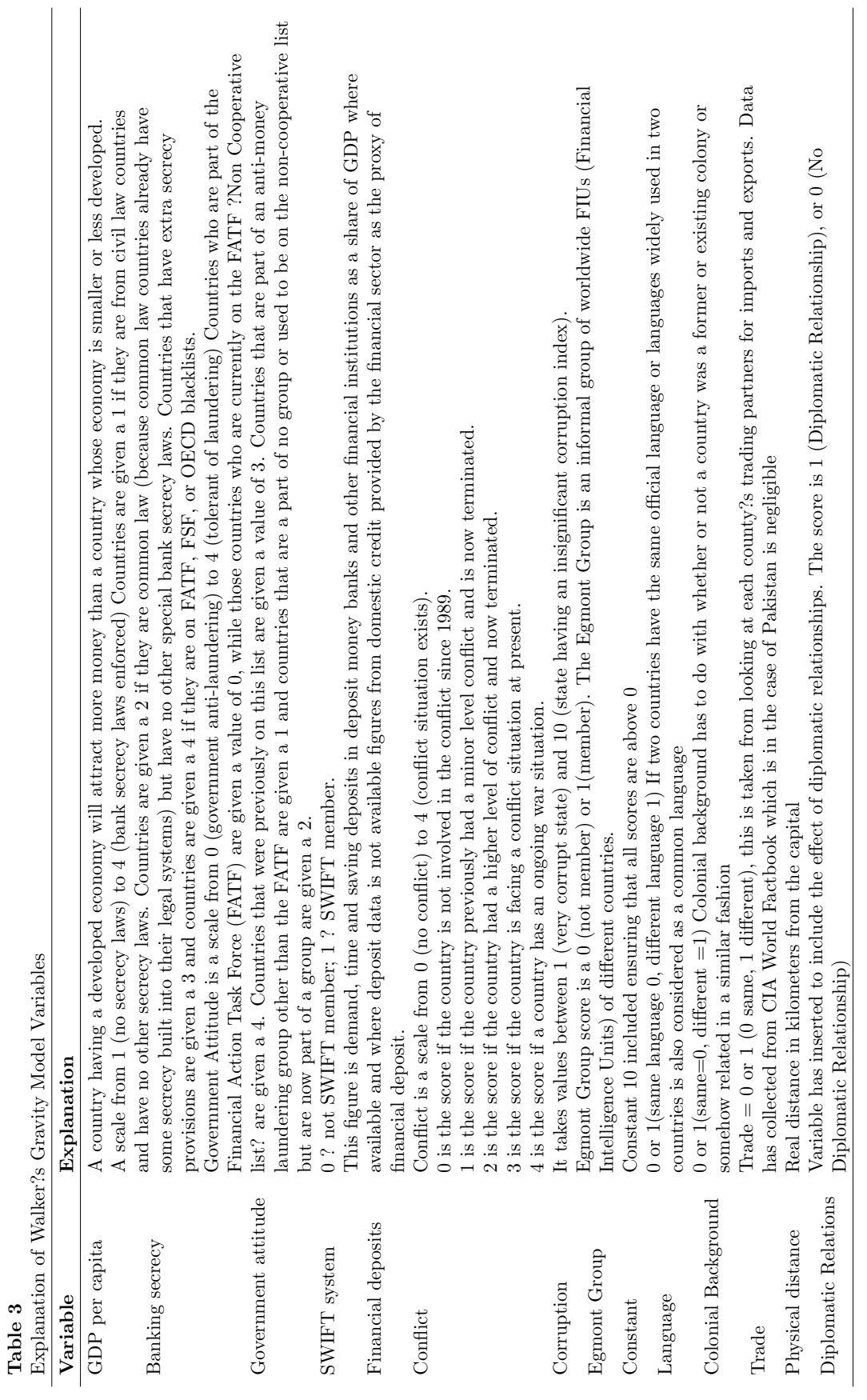


4. SWIFT System: Adoption of swift reflects the technological advancement while transferring money, more technological advancement means greater ease for money laundering.

5. Financial Deposit: This variable reflects the state of financial sector in a country. A sophisticated and developed financial sector offers more products and services to their customers including the wrong doers and also provides luxury to hide their ill gotten wealth.

6. Conflict: Countries with active conflicts or have history of conflicts are less attractive to money launderers as there are added chances of losing the money in case those conflicts intensified.

7. Corruption: Theoretically, corrupt states deemed to be more preferred destinations for money laundering, but no one wants to give an additional share from their wealth to anyone. Therefore, destinations with less corruption are always preferred for money laundering.

8. Egmont Group: This variable is also added to give more weightage to Country's attitude towards money laundering by including international cooperation perspective.

9. Constant: Constant has been added to avoid negative values due to nature of formula.

10. Language: Countries with common language are considered more desirable for doing business and transactions due to simplicity and fewer barriers, same will be the case in doing illicit business.

11. Colonial background: Same colonial background means two countries may have certain things in common including laws, culture and way of doing business, it all aids money launderers to execute their operations.

12. Trade: Strong trade relationship between two countries help the wrong doers to hide their illegal flow of funds under the umbrella of trade base transactions.

13. Physical Distance: With the globalization of financial markets, physical distance is not a major restrain in financial flow but still play a role.

14. Diplomatic Relationship: If a country does not have diplomatic relationship with another country values of all other variables nullify as there is no official relationship among them.

\section{Data Analysis and Results}

The attractiveness of most favored destination is calculated with respect to 15 developing countries with the highest illicit funds flow (IFF) according to Global Integrity Report. Data from the year 2002 to 2014 has been collected and analyzed from up to 156 countries where these illegal funds are landed for purpose of money laundering. Table 4 shows top 
25 most attractive countries for money launderers to clean their ill gotten wealth along with their attractiveness score.

\begin{tabular}{lll} 
Table 4 \\
List of Top 25 Most & \\
\hline 1 & Sttractive Countries \\
2 & Luxembourg & 7.84 \\
3 & Switzerland & 5.77 \\
4 & Hong Kong & 5.65 \\
5 & United States & 5.24 \\
6 & Panama & 4.04 \\
7 & Japan & 4.42 \\
8 & Cyprus & 4.38 \\
9 & Iceland & 4.35 \\
10 & Malaysia & 4.28 \\
11 & Macau & 4.08 \\
12 & Denmark & 4.05 \\
13 & Bahamas, The & 3.57 \\
14 & Ireland & 3.54 \\
15 & Brunei & 3.53 \\
16 & United Kingdom & 3.15 \\
17 & Canada & 2.83 \\
18 & Sweden & 2.74 \\
19 & Grenada & 2.62 \\
20 & Trinidad \& Tobago & 2.59 \\
21 & Austria & 2.57 \\
22 & Germany & 2.5 \\
23 & Korea, South & 2.46 \\
24 & Australia & 2.45 \\
25 & Netherlands & 2.43 \\
\hline
\end{tabular}

According to results top most position is held by Singapore, a jurisdiction of prime concern was considered by US Department of State International Narcotics Control Strategy Report (INCSR) in 2016. There is a strong system implemented in the country to identify and counter money laundering activities but because of Singapore's openness, low tax rate and a number of foreign funds managed in the country FATF also show concern on Singapore. According to FATF estimations the funds managed in Singapore are consisting of $77 \%$ of foreign funds ${ }^{3}$. Therefore, these mentioned characteristics make Singapore an attractive destination for money laundering. Next two positions are held by two of the most infamous countries that are Luxembourg and Switzerland respectively. Both destinations are always remained a choice for tax evaders, corrupt politicians and other organized crime doers because of traditional banking secrecy presences, low tax rates, sophisticated financial service sector and an ease in moving funds to and from these two countries. Remaining of list consist of countries with different attributes including global and regional financial hubs like United States of America, United Kingdom, Hong Kong, Malaysia, Japan and Cyprus. Many of above mentioned countries also have strong banking secrecy laws which also attract money launderers.

Countries with low tax rates like Germany, Brunei, Canada, Ireland and Denmark are also preferred by money launderers because it will cost them less to channelize the illegal wealth from these countries. In recent times Panama papers and then Bahamas leaks create uproar in different countries as it reveals the wealth accumulated by people of different countries in those two countries. Results also show the presence of both countries

\footnotetext{
${ }^{3}$ www.fatf-gafi.org/media/fatf/documents/reports/mer4/MER-Singapore-2016.pdf
} 
that is Panama and The Bahamas in top 15 countries slot.

\section{Robustness Check}

Robustness of data analysis and estimates are checked through triangulation with services industry statistics, FDI statistics and 'Mafia Type' reputed countries.

\section{Triangulation with Services Industry Statistics}

It is suggested that countries with strong services sector are more attractive for money launderers. Same is also implied; they concluded that jurisdictions having strong services industry composition in GDP are more preferred for money laundering. Our estimates also confirm above statement as a following mentioned list of most favored destinations has some well established services industry including financial sector and tourist industry. The below mentioned table shows that twenty countries out of twenty five most preferred countries have GDP composed of above and around $70 \%$ of the services industry.

\begin{tabular}{|c|c|c|c|c|c|}
\hline 1 & Macau & $91.50 \%$ & 14 & Sweden & $69.91 \%$ \\
\hline 2 & Hong Kong & $90.93 \%$ & 15 & Canada & $69.80 \%$ \\
\hline 3 & Bahamas, The & $89.34 \%$ & 16 & Singapore & $69.74 \%$ \\
\hline 4 & Luxembourg & $83.32 \%$ & 17 & Iceland & $69.24 \%$ \\
\hline 5 & United States & $78.45 \%$ & 18 & Germany & $68.61 \%$ \\
\hline 6 & Panama & $77.26 \%$ & 19 & Austria & $68.17 \%$ \\
\hline 7 & Cyprus & $77.11 \%$ & 20 & Switzerland & $67.43 \%$ \\
\hline 8 & United Kingdom & $75.91 \%$ & 21 & Korea, South & $57.06 \%$ \\
\hline 9 & Grenada & $75.37 \%$ & 22 & Ireland & $56.14 \%$ \\
\hline 10 & Denmark & $74.34 \%$ & 23 & Malaysia & $49.01 \%$ \\
\hline 11 & Netherlands & $72.66 \%$ & 24 & Trinidad \& Tobago & $46.08 \%$ \\
\hline 12 & Japan & $72.09 \%$ & 25 & Brunei & $36.24 \%$ \\
\hline 13 & Australia & $70.11 \%$ & & & \\
\hline
\end{tabular}

\section{Triangulation with Foreign Direct Investment Statistics}

Perez (2012) suggested that foreign direct investment (FDI) is used as a tool by money launderers to move their illegal money across the world. Every country encourages foreign investors as these funds strengthen their financial sector. It brings low cost finance to different sectors of the economy. Sometimes this eagerness of getting hold of such funds is exploited by wrongdoers. It is also implied by Ferwerda (2009), according to the study that financial institutions generate more profits from the funds flowed in for laundering purpose as well as it will increase the availability of low-cost credit for legal businesses in different sectors of the economy. Manjula (2011) suggests that FDI encourages illegal economic crimes like money laundering. Same is also suggested that the funds which move abroad illegally get foreign nationality and come back as FDI.

Table 6 shows the list of countries which remains in top 50 slots for receiving highest FDI from the year 2007 to 2015, the list consists of 34 of those countries which are also present in our top 50 list of most preferred destination list. This analysis validates the above statements that FDI is used by money launderers to conceal the movement of illegal money from one jurisdiction to another. 


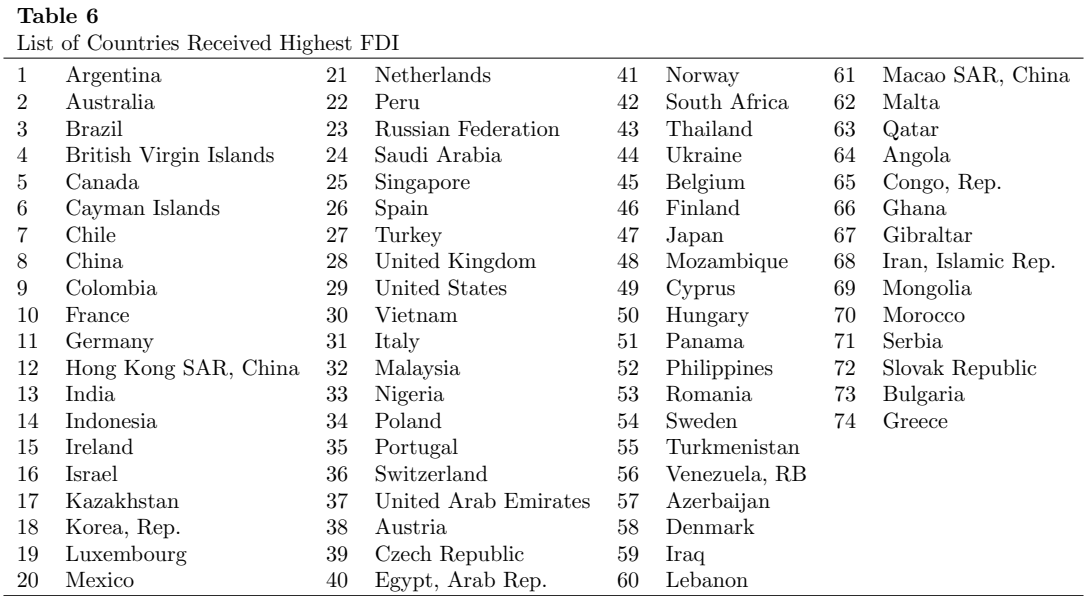

\section{Countries with "Mafia Type" Reputation}

It is suggested that countries have strong criminal gangs, better known as mafias have more likelihood to involve in money laundering activities as these organized and established criminal organizations have more power to control government decisions. Results from Schneider and Windischbauer (2008) also ascertained the same. The outcome of current research also confirms that mafia organization with strong links in economic and political circles have an impact on money laundering activities. In the next section, countries with a strong presence of organized criminal groups are discussed.

Due to globalization and technological advancement now activities of organized criminal gangs are not restricted to their origin but spread over the globe based on their operations. Naím (2012) also suggest the same that criminal networks spread out in last two decades and not restricted to traditional markets because of political and economic transfusion and technological advancement. There is a high demand for illegal products and services in North America which links the continent with mafia gang which can supply the same to desired users. Albanese (2004) states criminal gangs from Asia and Eastern Europe find North America a lucrative market because of demand of illegal products and services. The study also suggests that there is a strong presence of Italian organized criminal groups in the region.

It is interesting to know that developed countries in Western Europe also have a strong presence of international mafias with foreign origin. Gangs from Asia and South America are working in developed part of the continent along with Eastern Europe criminal organizations which escalate after fall of Soviet Union. European crime landscape consists of organizations within and outside of Europe and also has the significant existence of groups from Balkan countries and former soviet bloc. Criminals always look for established financial centers to launder their illegal wealth with ease and less fear. Western Europe with strong financial institutions and ease to move funds within the continent makes a perfect place to clean the money attained through illegal methods. A report prepared by Federal Research Division, Library of Congress in 2002 suggests the same that Western Europe 
provides the most favorable conditions to traffickers, arms dealers and corrupt officials to launder their money with strong financial sectors and the service provided by professionals.

Above discussion confirms the presence of mafia type organized gangs in the developed part of the globe including North America and Western Europe. Therefore, our analyses are backed by the assumption of Unger et al. (2006); Schneider and Windischbauer (2008) that countries with 'Mafia Type' reputation have more tendencies to involve in money laundering activities as our list is more populated with developed countries of the same part of the world. Hagedorn (2005) stated that it is not necessary that existence of criminal gangs is associated with violence and it varies between different countries. Therefore, low rate of violence in developed part of the world does not mean that no organized criminal gangs exist there.

\section{Conclusion and Recommendations}

Money laundering has vast and bitter consequences and it erodes every sector of a country. Criminals are always in need and try new ways to launder their illegal wealth. Assessment of related literature highlights that quantification of amount laundered and the other related estimations are less focused by researchers despite the fact that it is quite important to determine the size of the problem to counter it. This study determines the most preferred destination for money laundering from developing countries and also highlights the key features of these destinations which make them most preferred ones among them.

Watchful analysis of data highlights some of the main attributes of countries including strong economic conditions. List of top twenty five countries comprises of mainly top economies of the world. These larger economies provide perfect places to hide illegal money which enters into the system for the purpose of laundering. Developed economies also provide finest financial services to their customers because of technological advancement and strong financial sector. Jurisdictions having low tax rates and relax regulations for foreign funds inflows are also of prime concern for those who are fighting against money laundering because it will make easy for wrongdoers to legitimize their ill gotten money. Therefore, it is necessary that developed countries should adopt strong regulations and formulate comprehensive laws to empower their concerned authorities. United States efforts to counter financing terrorism after $9 / 11$ attacks is a good example in this scenario as formulation and implementation of US Patriot Act empower country's law enforcement agencies and judicial system to fight against terrorism financing effectively.

Results also underline some jurisdictions which may deliberately relax the laws and regulations to attract more foreign funds. Countries like Cyprus, Macau, Panama and many Caribbean countries intentionally allow the establishment of such firms which aid criminals and other wrongdoers to channel their funds through their financial sectors. This attracts much needed foreign investments in these countries on the cost of an increase in criminal activities at the global level. Many multinational financial institutions also operate from such havens to facilitate their customers in money laundering process. These malpractices can be eradicated through the implementation of rules and regulations at the global level. Global pressure, penalties and sanctions also play an important role in the 
elimination of this unethical and unlawful conduct. It is the global pressure which helps in the lifting of banking secrecy laws in Switzerland. Belize also faces strong opposition from developed countries when tried to enforce a controversial policy of not to question large foreign remittances and investments. Hong Kong Shanghai Banking Corporation (HSBC) is also forced to close its Cayman operations which are used by the bank to move illicit money to sanctioned jurisdictions after the United States fined the institution. Therefore, strong international regulations and embargoes work effectively in preventing financial institutions as well as countries from becoming part of money laundering activities.

Review of related literature and analysis of statistics shows that globalization also plays an important role in whole process of money laundering. Due to globalization and advancement in technology entire process of money laundering become timeless and unproblematic, now the transfer of funds anywhere across the globe does not require any troublesome process and can be done by just a click of button. In fact, with the aid of financial consultants, the whole process is completed in a very efficient manner without any risk. No one can suggest that globalization efforts should be restricted but there should be a set of regulation to fight money laundering at the global level. Every country should implement uniform regulations so that no jurisdiction remains attractive for money launderers due to lax controls. The absence of any regulatory body at international level is highly felt and the role of an agency like FATF should be upgraded from policy making body to law enforcement agency for effective implementation of policy in relation to global anti money laundering regime.

In a nutshell it can be easily concluded that joint efforts at the global level are mandatory to eliminate the problem of money laundering because if the efforts are not synchronized then it will only result in a change of places preferred by money launderers and they only have to switch the places which are more suitable for them. The need to determine the preferred destination for money laundering cannot be overlooked because it will assist in developing and implementing effective and targeted policies to counter money laundering activities.

\section{Research Implications}

The study gives an indication to policy makers at global level to formulate the guidelines and procedures as this paper suggests that more attractive recipients of illegal flow of funds are from developed world and still the world is pressing the underdeveloped countries to adopt strict policies to make the things right. With the conclusion that developed countries with big economies and strong financial sectors possess more attributes of financial havens for illicit flow of funds, the study invites academician to explore this point of view further to make more effective and result oriented policies to counter money laundering and illegal flow of funds. 


\section{References}

Albanese, J. S. (2004). North american organised crime. Global Crime, 6(1), 8-18.

Bartlett, B. L. (2002). The negative effects of money laundering on economic development. Platypus Magazine(77), 18-23.

Colladon, A. F., \& Remondi, E. (2017). Using social network analysis to prevent money laundering. Expert Systems with Applications, 67, 49-58.

Comstock, M. B. (1994). Gatt and gats: A public morals attack on money laundering. Nw. J. Int'l L. EG Bus., 15, 139.

Demetis, D. S. (2018). Fighting money laundering with technology: A case study of Bank $\mathrm{X}$ in the UK. Decision Support Systems, 105, 96-107.

Ferwerda, J. (2009). The economics of crime and money laundering: Does anti-money laundering policy reduce crime? Review of Law \& Economics, 5(2), 903-929.

Fontana, A. (2010). 'what does not get measured, does not get done'. The methods and limitations of measuring illicit financial flows. U4 Brief.

Gjoni, M., Gjoni, A., \& Kora, H. (2015). Money laundering effects. In Proceedings of 4 th ubt annual international conference on business, technology and innovation (p. 13).

Hagedorn, J. M. (2005). The global impact of gangs. Journal of Contemporary Criminal Justice, 21(2), 153-169.

Hetemi, A., Merovci, S., \& Gulhan, O. (2018). Consequences of money laundering on economic growth-the case of Kosovo and its trade partners. Acta Universitatis Danubius. Economica, $14(3)$.

Khan, W. A., Jawaid, S. T., \& Arif, I. (2018). Where does a nation's wealth go? evidence from a third world country. Journal of Money Laundering Control, 21 (3), 426-476.

Kumar, V. A. (2012). Money laundering: Concept, significance and its impact. European Journal of Business and Management, 4(2).

Myint, U. (2000). Corruption: Causes, consequences and cures. Asia Pacific Development Journal, 7(2), 33-58.

Naím, M. (2012). Mafia states: Organized crime takes office. Foreign Aff., 91, 100.

Nkurunziza, J. D. (2012). Illicit financial flows: a constraint on poverty reduction in Africa. ACAS Bulletin, 87, 15-21.

Pol, R. F. (2018). Anti-money laundering effectiveness: Assessing outcomes or ticking boxes? Journal of money laundering control.

Schneider, F., \& Windischbauer, U. (2008). Money laundering: some facts. European Journal of Law and Economics, 26(3), 387-404.

Sharman, J. C. (2008). Power and discourse in policy diffusion: Anti-money laundering in developing states. International Studies Quarterly, 52(3), 635-656.

Shelley, L. I. (1995). Transnational organized crime: An imminent threat to the nationstate? Journal of International Affairs, 463-489.

Unger, B., Rawlings, G., Siegel, M., Ferwerda, J., de Kruijf, W., Busuioic, M., \& Wokke, K. (2006). The amounts and effects of money laundering (Report for the Ministry of Finance). Utrecht: Utrecht School of Economics, Australian National University. 